International Journal of Physical Sciences and Engineering
Available online at http://sciencescholar.us/journal/index.php/ijpse
Vol. 1 No. 2, August 2017, pages: $1 \sim 10$
e-ISSN : 2550-6943, p-ISSN : 2550-6951
http://dx.doi.org/10.21744/ijpse.v1i2.28

\title{
Roadmap for the Introduction of Smart Grids in Ecuador
}

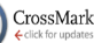 \\ Guillermo Antonio Loor Castillo a; Lenin Agustín Cuenca Álava b; Miguel Castro \\ Fernández $^{c}$; Miriam Vilaragout Llanes ${ }^{\mathrm{d}}$ \\ Article history: Received 5 January 2017 ; Accepted in revised form 10 July 2017 ; Approved 21 July 2017 ;
} Available online 1 August 2017

Guillermo A. Loor Castillo a

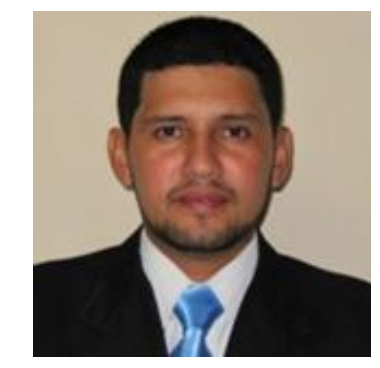

Keywords

Distributed generation;

Ecuador expose;

Electrical service;

Renewable energy;

Smart grids;
Abstract

Distributed generation and smart grids are the reality of an efficient electricity grid, at work an analysis of the advantages that distinguish both concepts related to the scenario generation, transportation, distribution and supply of energy is provided. Some results achieved in the related study of the solar potential and wind energy, focused on the use of these resources will improve in quality future university exposed electrical service. The main elements that have been considered to be incorporated in the roadmap for the introduction of smart grids in Ecuador expose.

e-ISSN : 2550-6943, $p$-ISSN : 2550-6951@ Copyright 2017. The Author. SS Journals Published by Universidad Técnica de Manabí. This is an open-access article under the CC BY-SA 4.0 license (https://creativecommons.org/licenses/by-sa/4.0/) All rights reserved.

a Doctorate program Universidad Técnica de Manabí, Faculty of Mathematical, Physical and Chemical Sciences, Portoviejo, Manabí, Ecuador

b Doctorate program Universidad Técnica de Manabí, Faculty of Mathematical, Physical and Chemical Sciences, Portoviejo, Manabí, Ecuador

c Ph.D. Dean of the Faculty of Electrical Engineering, Universidad Tecnológica de La Habana

d Ph.D. Lecturer at the Faculty of Electrical Engineering, Universidad Tecnológica de La Habana 


\section{Contents}

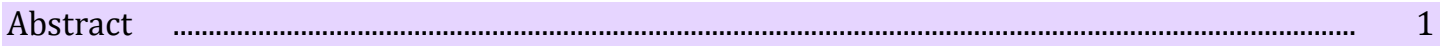

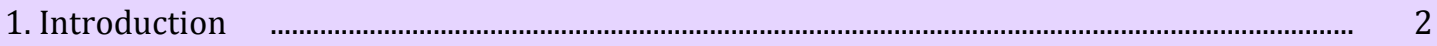

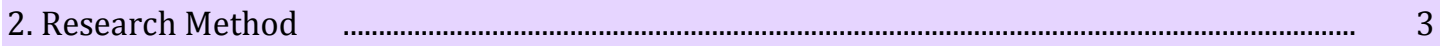

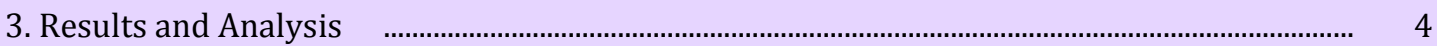

3.1 Distributed generation ……………………………………………………………………………....

3.2 Smart Grids...

3.3 Ability to take up the challenge

3.4 Roadmap.

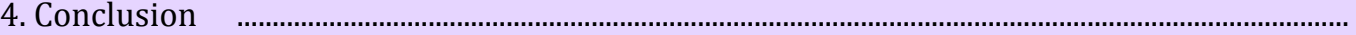

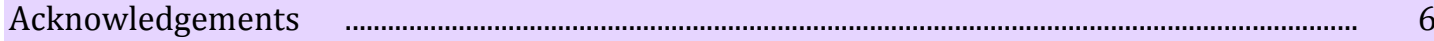

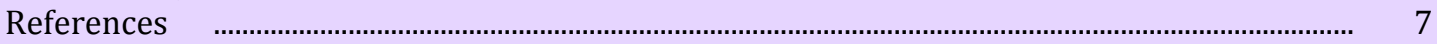

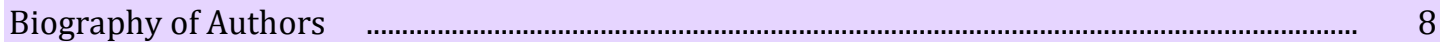

\section{Introduction}

For the next few years Ecuador must face different challenges aimed at achieving the country's development on a sustainable basis to ensure the equitable growth of society, among the most significant are: the increase in demand for electricity with a projection of a $55 \%$ in the 2005-2030 period; Face the trend of using more environmentally friendly technologies; High energy prices; Reduction of losses and; Combining the principles of distributed generation (GD) with the national interconnected system (SNI), making the large-scale technical scale of the centralized system more reduced and manageable [1].

Among the goals that must be achieved can be mentioned: the elevation of the reliability and quality of the electric service; Achieve the operational stability of the system; To reduce the environmental effects derived from the generation, transportation, distribution and supply of electric energy; Increase levels of efficiency by reducing losses and making greater use of available sources; Adequately articulate an efficient energy market, incorporating the customer into the generation of their own energy and control of consumption.

The trend is towards assimilating a new form of operation of the National Interconnected System through the increasingly important assimilation of distributed generation, technologies associated with intelligent micro grids and the presence of renewable energy sources, which will require of an adequacy of the preparation of the operators of the system, allowing them to adequately manage the characteristics of the new technologies and the new sources that are incorporated.

\section{Research Method}

It was based on the inductive method to facilitate the analysis of the historical evolution of the traditional models of energy planning put into practice in the country, in its linear consideration for privileging the energy factor, above the environmental and social. It is also important to use the analysis-synthesis method in the study of available bibliographic material. The historical-logic for the provision of precise considerations regarding the logic of social development of the topic related to energy development, since its evolution in previous years.

The investigative techniques of revision of documents, texts and the regulatory framework were used to obtain the adequate and truthful information that implies in the arrival of certain considerations, on the technical design that must be assumed in relation to the electrical system and the use Of renewable energy sources.

It proposes the use of geographic information, oriented to renewable sources of energy, to achieve new results linked to the design of microelectrical networks, that propitiate to increase the efficiency and the saving of resources. 
For the cartographic information was used the one published in the regional scale website 1: 250.000, January 2013 version. Basic geographic information layers of the Institute of Military Geography (IGM) of free access [2].

In order to manage the information of the potentials related to solar and wind energy, information was used for the databases published on the NASA website [3].

\section{Results and Analysis}

\subsection{Distributed generation}

The GD is related to the production of electricity on a small scale, through systems that connect to the distribution or directly to the low voltage line of the user, in areas close to the loads or end consumers, where energy resources are close of consumer centers [4].

Frequently some specialists make the serious mistake of understanding GD as a new system of generation independent of the traditional power system, however the new thing that implies the use of GD is to coexist within the current electricity market, where small producers have The possibility of selling their energy and controlling their consumption [4].

Frequently some specialists make the serious mistake of understanding GD as a new system of generation independent of the traditional power system, however the new thing that implies the use of GD is to coexist within the current electricity market, where small producers have The possibility of selling their energy and controlling their consumption [4].

The most important thing to understand is that at present there is no other technical alternative that is better than DG to achieve the sustainable diversification of the current energy matrix, with the possibility of taking advantage of various sources available at the territorial level. The advantage can be the adoption of solutions to raise the quality of service and efficiency, as well as to promote the preservation of natural resources and environmental respect, ensuring the sustainability of the development of society [4].

In developing countries where there is not much pressure to take measures that stop global warming or where they can not adopt them to market clean development mechanisms and where there is generally no major concern about the depletion of fossil resources For electricity generation or have other resources such as hydroelectricity, the development of DG is incipient and is given little attention [5].

But above all considerations energy policy has become increasingly important in the development plans of countries, with emphasis on energy efficiency and the use of renewable sources. Within this context, distributed generation and the so-called intelligent networks [5].

\subsection{Smart Grids}

The immutable verticality of the current power grid, with unidirectional energy flows, with a centralized management and operation, needs to be transformed as a result of the introduction of new technologies that participate in the generation of electrical energy and advances in information technologies and communications [6].

The adoption of the distributed generation mode goes hand in hand with the application of intelligent networks, with the ability to offer technical solutions when properly combined with the centralized system. The development of power electronics, the improvement of communications reliability and the increase of the capacity of the storage media, are marking the step as previous elements to the intelligent systems [7].

Conceptually it can be defined that a network is intelligent, when it integrates the centralized generation through large generating plants, with distributed generation on a small scale where the renewable sources of energy already intervene, in which the user can consume and send Energy to the grid, ie the demand side of the grid can be converted in a controlled manner into a "source" or a "well" of energy [8], where large-scale information technologies And communication (ICT) systems that are traditionally associated with administrative information systems and operations technologies (OTs) with field equipment connected to the electrical system.

Castillo, G. A. L., Álava, L. A. C., Fernández, M. C., \& Llanes, M. V. (2017). Roadmap for the introduction of smart grids in Ecuador. International Journal of Physical Sciences and Engineering, 1(2), 1-10. https://doi.org/10.21744/ijpse.v1i2.28 
Smart Grids are based on incorporating electronic devices such as meters, controllers, sensors or controls into the traditional electrical grid; Linked through different communication technologies, achieving the centralization and use of information for the benefit of all the actors involved, optimizing the operation of the electrical system. In this way it is possible for consumers to efficiently manage their assets and for the end-user to manage their consumption in a rational way [9].

The concepts linked to smart grids represent a break with the traditional way of consuming all the energy coming from a centralized electrical system, based on large generation plants with an extensive system of transportation and distribution of electricity to its final destination. The system's built-in intelligence enables it to help meet growing electricity needs, increase service quality, increase efficiency by reducing losses, promote the preservation of natural resources and minimize environmental impact by helping to limit CO2 emissions to the atmosphere.

They are called intelligent networks because the devices that integrate it can be programmed with the capacity to make certain decisions without the intervention of the human factor.

\subsection{Ability to take up the challenge}

At present there is a growing interest in the use of renewable options for the change of the energy matrix. On the other hand, there is growing concern about the reduction of oil reserves and environmental pollution caused by the generation of electricity through the burning of oil, which has made the energy issue become a matter of prime necessity for the Ecuadorian government, Which in recent years has devoted considerable resources to the construction of projects that will allow the country's energy matrix to be redirected towards self-supply of electricity, the export of electric energy at the regional level and the change of the productive matrix [10].

At present, the hydrothermal park available in Ecuador consists of: 16 small, medium and large capacity hydroelectric power stations, as well as 39 small power plants belonging to electricity distribution companies, municipalities and private companies; More than a hundred thermal power stations with different fuels and belonging to various companies, including generators, distributors, private industry and oil companies in general. In addition to 4 non-conventional renewable generation plants (Ecoelectric, San Carlos, Ecudos and Villonaco). The main emblematic hydroelectric projects (Coca Codo Sinclair, Minas San Francisco, Delsintanisagua, Manduriacu, Mazar Dudas, Toachi Pilatón, Quijos and Blower) are currently in operation, except for two of them, which are expected to start generating by the end of this year and Income represents a relevant contribution to cover the projected electricity demand, guaranteeing energy sovereignty, with adequate levels of reserves [10].

On the other hand, in 2012, the National Institute of Energy Efficiency and Renewable Energies (INER) was created, responsible for the generation of technical knowledge applied in the definition of public policies, strategic planning, control, monitoring and evaluation of the sector, Promotion of technology transfer and innovation and the promotion of human talent specialized in electricity and renewable energies [10].

It is also necessary to mention the increase in end-user service coverage, which plays the most important role in the electrical industry, as well as the growing need for a reliable and quality service with energy efficiency, necessarily imply the expansion of The entire supply chain. To this are added the technological advances in small-scale renewable generation, metering and communications, specifying the automation of the electrical grids of distribution (smart grids), as well as the increase of the reliability and security of the transmission system and of course, The promotion and sustainable development of generation projects.

Ecuador has sufficient potential from renewable sources to achieve total oil independence in a short time. So far the main efforts have been made to exploit the hydraulic resource through traditional centralized generation and connected to the national interconnected 
system, as well as studies of wind and solar potential respond to the same interests. The publication of the Wind Atlas makes it easier to locate sites where measurement campaigns and subsequent prefeasibility and feasibility studies should be carried out for the possible construction of new wind farms [11].

Independently of the studies carried out under the direction and sponsorship of the Ministry of Electricity and Renewable Energies (MEER) of Ecuador, in the UTM the project Geographic Information System for Sustainable Development (SIGDES) [13] is developed, where Has carried out the study of the potential of winds at low altitude, as well as the map of the solar potential focused in the appropriation of these energy sources in the mode of the GD. At the same time, a project is being carried out to study and evaluate small hydroelectric potential in the province of Manabí, which will allow the development of small hydroelectric power systems focused on improving electricity service in rural areas and extending electrification to sites that have not yet Have this service [14].

Figure 1 shows the map of the solar potential and in Figure 2 the map of the wind potential made with free access information provided by the National Aeronautics and Space Administration (NASA) of the planet's meteorological parameters. This information was processed through a geographic information system (GIS), which is currently being implemented for sustainable energy development in the UTM (SIGDES), information that is dedicated to facilitate the introduction of facilities that take advantage of these renewable resources in the mode Of the DG [16], [17].
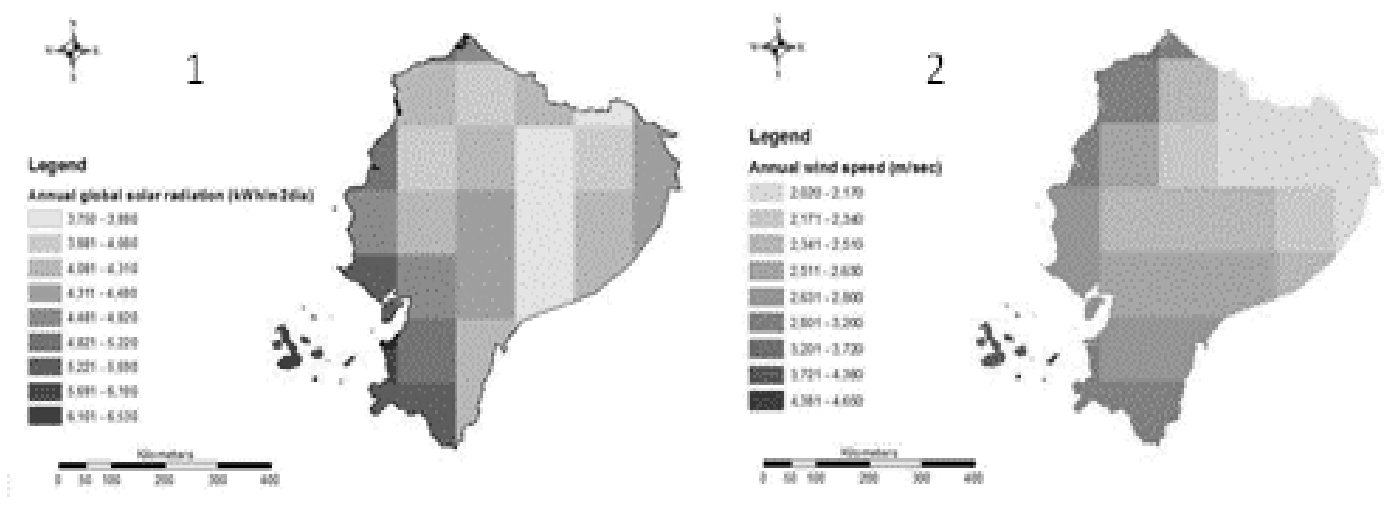

Figure 1. Map of solar potential (1) y Map of the wind potential (2)

The consideration of the environmental problems in the development from the globality that they need has changed a lot in recent years. What in the mid-twentieth century was a minor concern for species and spaces is today the center of a worldwide debate on the future of humanity.

It is inevitable for any country that looks to the sustainable progress of society, to be able to look away from the development that is happening every day in the energy sector and especially the technological changes that are operating in the new intelligent electric lines.

The MEER approved the ministerial agreement 301, which in its article 1 proposes to institutionalize the Ecuador Intelligent Networks Program (REDIE), with the purpose of having a more efficient and flexible network, with high availability and quality in the energy supply, sustained In the benefit of information and communication technologies, through the establishment of a single frame of reference for the management and execution of the different initiatives associated with this program [11].

REDIE is one of the means to facilitate the integration of different actors, technologies, standards and standards, aimed at promoting the efficient use of energy, reducing emissions and reinforcing the security and quality of electricity supply.

Castillo, G. A. L., Álava, L. A. C., Fernández, M. C., \& Llanes, M. V. (2017). Roadmap for the introduction of smart grids in Ecuador. International Journal of Physical Sciences and Engineering, 1(2), 1-10. https://doi.org/10.21744/ijpse.v1i2.28 
In Article 2, the creation of an executive committee for the execution of the program is endorsed and among its functions the parameters to be filled in the roadmap are established, these parameters are shown in the diagram of figure 2 [12].

\subsection{Roadmap}

In figure 2, a pyramid is shown directed to the desired route of the intelligent networks in Ecuador.

\section{Route}

$$
\begin{aligned}
& \text { Approve the } \\
& \text { annual budget } \\
& \text { of the Program }
\end{aligned}
$$

Manage resource availability

Approve the different development plans

Approve program updates

Develop a scheme or structure that guarantees the organization, operation and management of the program

Evaluate program compliance, progress and effectiveness

Communicate the program to the different groups of interest of the country and promote its implementation

To know and resolve issues that, due to their importance and competence, are requested from the Technical Committee

Figure 2. Roadmap

The REDIE roadmap is expected to ensure the characteristics of Ecuador's new smart grid, as shown in the diagram in Figure 3. 


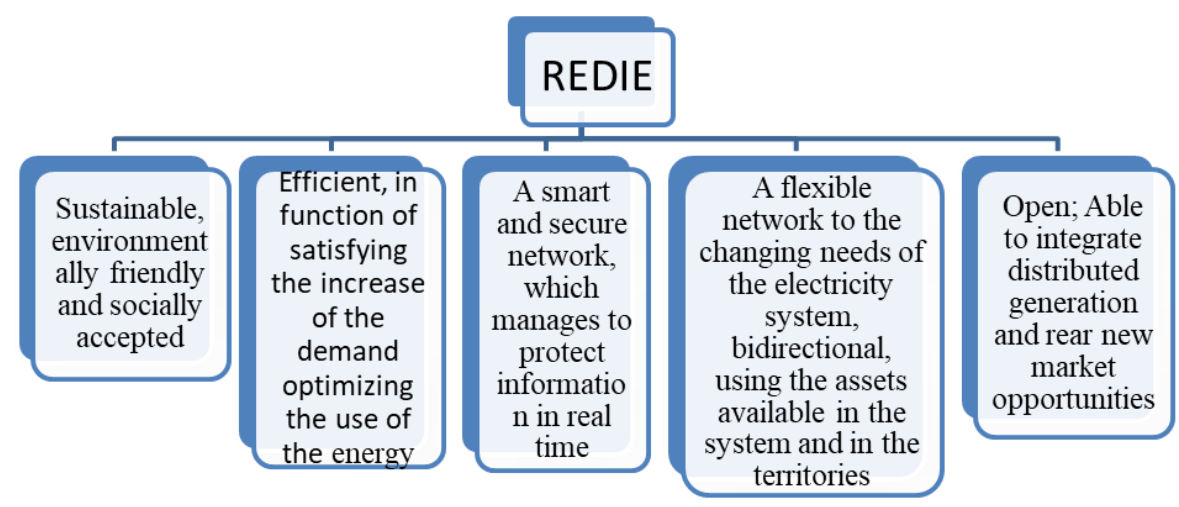

Figure 3. Characteristics of the new smart grid

In the new design of the electrical network, it is planned to move from a centralized model of one to many, to a decentralized and bidirectional model of many to many. Making adaptations in real time to respond to the continuous changes in demand demand are characteristics of the new electricity network. Properly combine centralized generation with unidirectional energy flows to the DG with bidirectional energy flows, where users can participate in a sort of dynamic behavior of the system.

Figure 4 shows a technical diagram of the new smart grid that is intended to be structured in Ecuador.

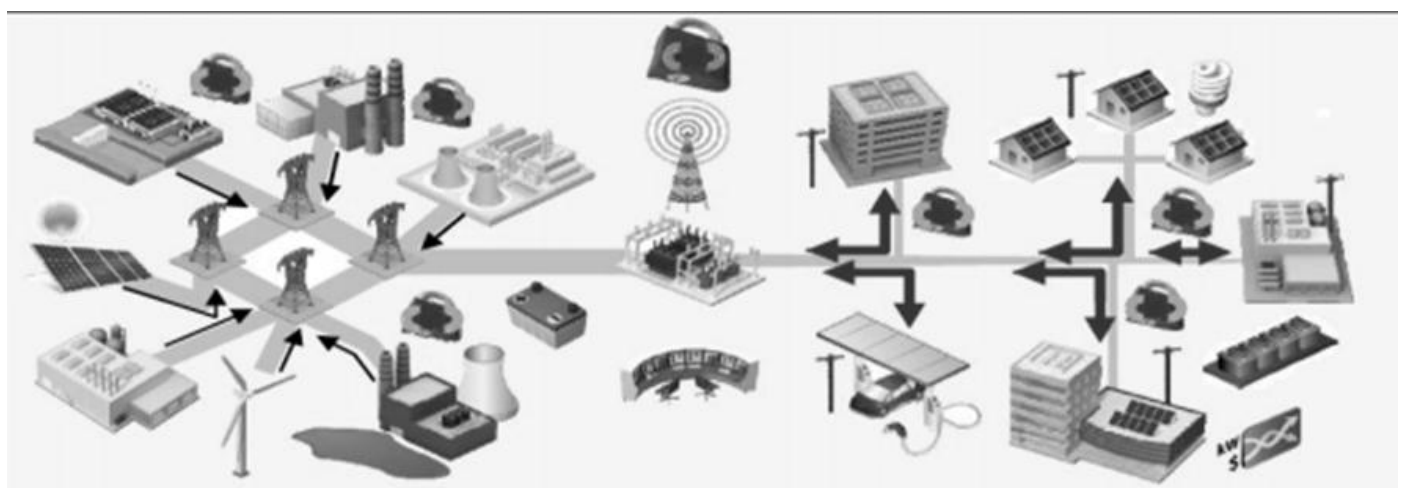

Source: [17]

Figure 4. Technical diagram of the new smart grid

The road map foresees between 2013 to 2017 carry out the following activities by areas that are shown in the diagram of figure 5.

Castillo, G. A. L., Álava, L. A. C., Fernández, M. C., \& Llanes, M. V. (2017). Roadmap for the introduction of smart grids in Ecuador. International Journal of Physical Sciences and Engineering, 1(2), 1-10. https://doi.org/10.21744/ijpse.v1i2.28 


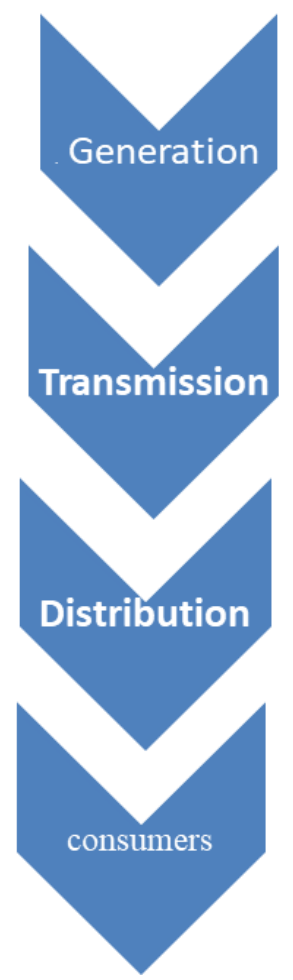

- To carry out the updating of the existing plants and the studies of the potential of small hydropower plants, wind power, and the rest of the renewable sources; Execution of GD expansion planning for isolated and non-supply areas with the integration of renewable energy into the grid.

- Implement the migration plan towards IEC61850 Backbone information and data collection, as well as implementation of Systemic Protection Advanced substations (digital) PMUs.

- SCADA-OMS-MWM system; GIS system/Asset management; Automation of distribution substations; Information backbone and data collection; Advanced distribution infrastructure; Advanced measurement infrastructure (CIS-MDM-CRM); Automation of distribution networks, control and supervision of VE and VE load stations; Asset Management; Efficient public lighting (smart); VOLT / VAR control, voltage reduction (CVR); Control and supervision of VE and VE load stations.

- In terms of: Introduction of efficient end-use equipment; Articulation of energy efficiency programs; Introduction of individual electric transport and massive electric transport.

Figure 5. Activities by area

Ecuador's road map for the introduction of smart grids is already underway, with the awareness that a perfect work has not been achieved and that, like all human labor, it is likely to be characterized by elements of development that can later be incorporated To the extent that the operational adjustments are made to the plans and projects of realization, however it can already be noticed as institutional purpose the lack of the element of training and overcoming the human resources that will make the project a reality. In no case is it appreciated the use of Ecuador's extraordinary capacity for training and development of knowledge in its universities, institutes and research centers, which are distributed throughout the national territory and where projects linked to sustainable development And the appropriation of the local resources that are available in the territories.

Ecuador's road map for the introduction of smart grids is already underway, with the awareness that a perfect work has not been achieved and that, like all human labor, it is likely to be characterized by elements of development that can later be incorporated To the extent that the operational adjustments are made to the plans and projects of realization, however it can already be noticed as institutional purpose the lack of the element of training and overcoming the human resources that will make the project a reality. In no case is it appreciated the use of Ecuador's extraordinary capacity for training and development of knowledge in its universities, institutes and research centers, which are distributed throughout the national territory and where projects linked to sustainable development And the appropriation of the local resources that are available in the territories.

\section{Conclusion}

The research made it possible to verify that since 2013 a group of institutional actions have been carried out in Ecuador, in order to achieve the articulation in the country of intelligent networks, for which it has been elaborated and is in the stage of being updated and updated a A route focused on organizing, planning and executing the activities and actions that in the 
technical order involve the realization of changes and transformations of a unidirectional network, in an automated, bidirectional and integrated network with artificial intelligence devices and renewable energy sources.

\section{Acknowledgement}

The group of researchers thanks the administration of the Technical University of Manabí for the support in the realization of the investigation.

\section{References}

1. SENPLADES, Plan Nacional del Buen Vivir 2013-2017. Secretaría Nacional de Planificación y Desarrollo - Senplades, 2013. Quito, Ecuador (primera edición, 11000 ejemplares), 2013. ISBN-978-9942-07-448-5. www.buenvivir.gob.ec

2. IGM, Basic Geographic Information

Layers http://www.geoportaligm.gob.ec/portal/index.php/descargas/cartografia-de-libre-acceso/carto, 2013.

3. Whitlock, $\mathrm{CH}$, Release 3 NASA surface meteorology and solar energy data set For renewable energy industry use Proceedings of Rise and Shine, 2000. Accessed January 15, 2015.

4. Herrera Jorge, Normativa Chilena referida a Generación Distribuida como Agente del Mercado Eléctrico. EIE561 Distribución Eléctrica PUCV, Ingeniería Civil Eléctrica, EIE, PUCV - CHILE, 2009. Student Member IEEE.

5. Álvarez Carlos Andrés and Serna Francisco Javier, Análisis local y mundial de tendencias en generación distribuida. $\begin{array}{llllll}\text { Consultado } & \text { el } & 25 & \text { de } & \text { agosto } & \text { de }\end{array}$ http://www.cidet.org.co/sites/default/files/documentos/uiet/analisis_local_y_mundial_d_tendencias_en_ generacion_distribuida_2012

6. Vázquez Antronio. La Formación Ambiental desde el aprovechamiento de la energía solar, el ahorro y la eficiencia energética. Estudio de caso Universidad Técnica de Manabí. Instituto Internacional de Formación Ambiental. Valladolid España, 2016. Memoria del Proyecto de Fin de Máster.

7. Rodriguez H. Alberto, La Generación Distribuida y su posible integración al Sistema Interconectado Nacional. Comición de Regulación de Energía y Gas (CREG ). Bogota. http://www.naturgas.com.co/uploads/2016

8. Velázquez Raúl, Introdución al concepto de micro redes. Boletín IIE, Tendencias tecnológicas, 2010. http://www.iie.org.mx

9. Medina Ricardo, Microrredes eléctricas. Electricidad en un ambiente inteligente. web Academía. 2012. http://www.academia.edu

10. Velazcos R, Redes de transmisión inteligente. Beneficios y riesgos. Smart Transmission Grids Benefits and Risks. Ingeniería Investigación y Tecnología, volumen XIV (número1), enero-marzo 2013: 81-88. ISSN 1405-7743 FI-UNAM, 20013. Instituto de Ingeniería. Universidad Nacional Autónoma de México.

11. MEER, Redes Inteligentes y Generación Distribuida. Ministerio de Electricidad y Energía Renovable del Ecuador, 2015. Consultado enero 2015. Disponible en: http://www.iner.gob.ec

12. MEER, Plan Estrategico Institucional 2014-2017. Ministerio de Electricidad y Energia Renovable, 2014. Consultado el 16 de octubre de 2016. Disponible en: http://www.energia.gob.ec

13. Ecuador, F., Atlas Eólico de Ecuador. Consultado el 10 de octubre de 2016 . Disponible en: http://www.forosecuador.ec/forum/ecuador/educaci\%C3\%B3n-y-ciencia/3470-atlas-e\%C3\%B3lico-de-ecuador, 2016.

14. W. Manuel Saltos Arauz, María Rodríguez Gámez, Antonio Vázquez Pérez, Miguel Castro Fernández. Microgrids Views from a Geographic Information System. International Research Journal of Engineering, IT \& Scientific Research (IRJEIS) Available online at http://ijcu.us/online/journal/index.php/irjeis, Vol. 2, Issue 11, November 2016, pages: 51 57, ISSN: 2454-2261.

15. Antonio Vázquez Pérez, et al., The Regulatory Framework For Renewable Energy Sources. International Research Journal of Management, IT \& Social Sciences (IRJMIS). http://ijcu.us Thomson Reuters: K-4291-2016, 2016. ISSN: 2395-7492 Impact Factor: 3.552.

16. Esteban Albornoz V, Acuerdo Ministerial 301. . Ministerio de Electricidad y Energía Renovable, 2013. Consultado el 10 de octubre de 2016. Disponible en: http://www.cenace.org.ec/

17. REDIE, Redes Inteligentes de Generación Distribuida. Ministerio de Electricidad y Energia Renovable, 2016. http://www.iner.gob.ec

18. Vivas, F. E. V., Cuello, R. L. C., Macías, D. M., \& Rosado, G. P. (2017). Elaboration of Essential Oil from the Oregano for Medicinal Use Sheet. International Journal of Physical Sciences and Engineering (IJPSE), 1(1), 81-87.

19. Jain, P., Billaiya, R., \& Malaiya, S. (2017). A Correlational Analysis of Academic Stress in Adolescents in Respect of Socio-Economic Status. International Journal of Physical Sciences and Engineering (IJPSE), 1(1), 68-71.

20. Castillo, G. A. L., Álava, L. A. C., Fernández, M. C., \& Llanes, M. V. (2017). Roadmap for the Introduction of Smart Grids in Ecuador. International Journal of Physical Sciences and Engineering (IJPSE), 1(2), 1-10.

21. Ogunsiji, A. S., \& Ladanu, W. K. (2017). A Theoretical Study of Performance Measures in the Strategic and Corporate Entrepreneurships of Firms. International Journal of Physical Sciences and Engineering (IJPSE), 1(1), 72-80.

22. Arauz, W. M. S., Cedeño, G. I., Chávez, S. S., Pérez, A. V., \& Gámez, M. R. (2017). Microgrid With a 3.4 kWp Photovoltaic System in the Universidad Técnica de Manabí. International Journal of Physical Sciences and Engineering (IJPSE), $1(2), 11-20$.

Castillo, G. A. L., Álava, L. A. C., Fernández, M. C., \& Llanes, M. V. (2017). Roadmap for the introduction of smart grids in Ecuador. International Journal of Physical Sciences and Engineering, 1(2), 1-10. https://doi.org/10.21744/ijpse.v1i2.28 
23. Suleiman, O. M. E. (2017). Linear Deflection of Laminated Composite Plates using Dynamic Relaxation Method. jiA, $6(2), 1$.

24. Suleiman, O. M. E. (2017). Deflection of Laminated Composite Plates Using Dynamic Relaxation Method. International Journal of Physical Sciences and Engineering (IJPSE), 1(1), 40-53.

25. Omer, A. M. (2017). Sustainable Development and Environmentally Friendly Energy Systems. International Journal of Physical Sciences and Engineering (IJPSE), 1(1), 1-39.

\section{Biography of Authors}

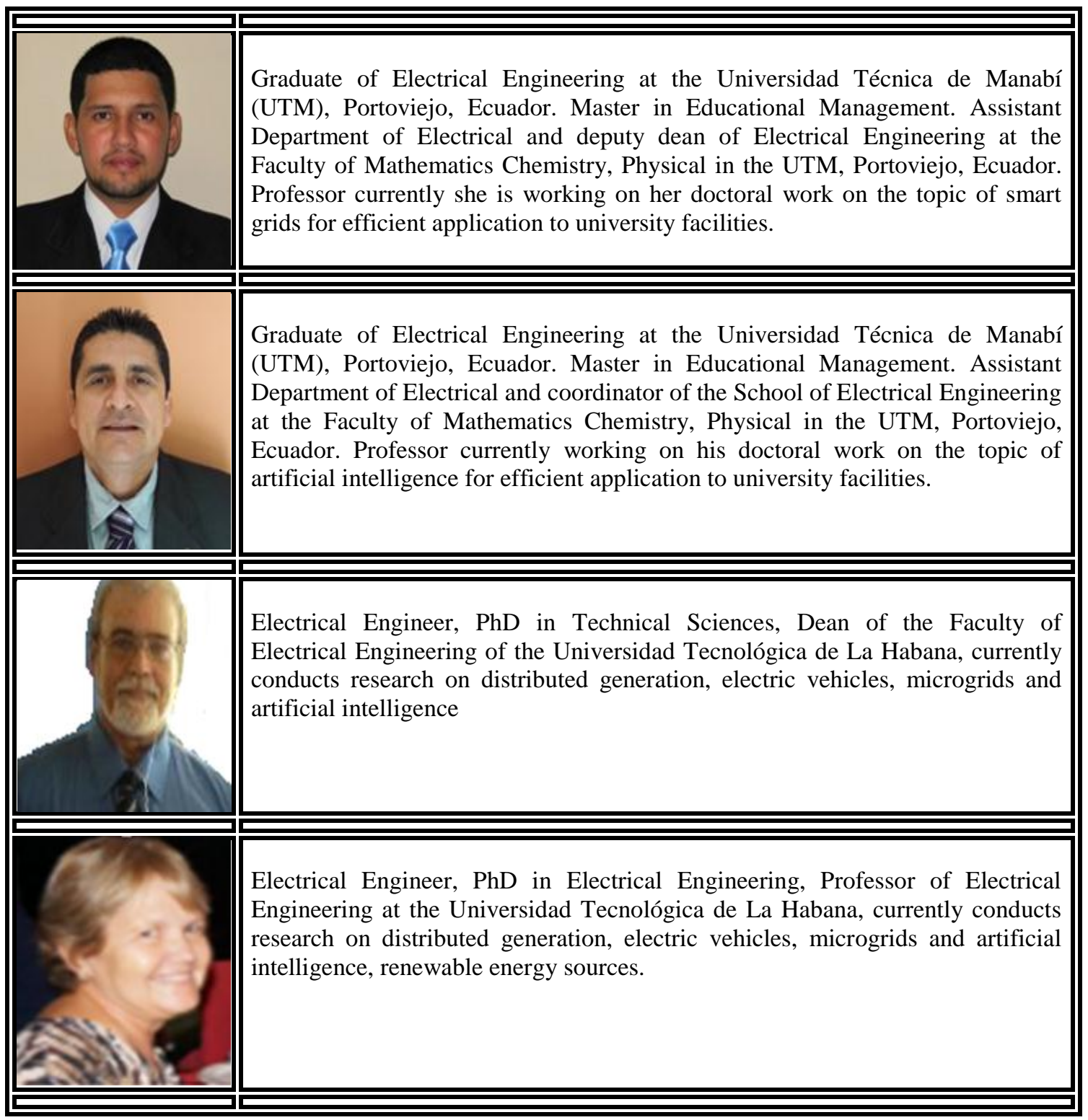

